\title{
Dietary copper intake in artificially fed infants
}

\author{
S SALIM, J FARQUHARSON, G C ARNEIL, F COCKBURN, G I FORBES, R W LOGAN, \\ J C SHERLOCK, AND T S WILSON
}

Department of Child Health, University of Glasgow*

SUMMARY Plasma concentrations of copper and zinc and leucocyte concentrations of zinc were measured in mothers during later pregnancy, at delivery, and 8-10 weeks after birth, and plasma concentrations of copper and zinc were measured in their infants at delivery and 8-10 weeks after birth. The 145 infants were either breast fed or fed one of two milk formulas supplying copper at different concentrations. None of the infants achieved the minimum copper intakes recommended by the World Health Organisation (WHO). At 2 months of age there were no major differences in growth or health detected in infants fed the different copper intakes. Infant birth weight correlated well with the ratio of maternal venous plasma zinc:maternal leucocyte zinc at delivery. Maternal venous plasma copper and zinc concentrations at birth correlated with umbilical venous plasma copper and zinc concentrations. Infants fed the higher copper content formulas had a low mean plasma zinc concentration without a significant increase in the mean plasma copper concentration. The present WHO recommendations regarding minimum copper intakes for infants fed formulas cannot be achieved with currently available formulas and are probably wrong.

During 1979 a survey of 131 infants born in Glasgow was made to investigate their dietary intakes of lead, and it was found that most of the dietary lead ingested by bottle fed infants came from tap water. ${ }^{1}$ Further analyses of a subsample, comprising 41 of the infants, showed that $37(90 \%)$ had intakes of copper below the World Health Organisation (WHO)/Food and Agricultural Organisation recommended safe minimum intake of $1.26 \mu \mathrm{mol}$ $(80 \mu \mathrm{g}) / \mathrm{kg}$ body weight per day and $33(80 \%)$ were below the recommended absolute minimum of $0.94 \mu \mathrm{mol}(60 \mu \mathrm{g}) / \mathrm{kg}$ body weight per day. A smaller proportion of the zinc intakes were also below recommended concentrations. In view of this it was decided to give the initial priority to a study of copper intakes. The purpose of the investigation now described was to examine the plasma concentrations of copper in the mothers during later pregnancy, at delivery, and 8-10 weeks later, and in the infants at delivery and 8-10 weeks after birth.

\footnotetext{
${ }^{*}$ For the Glasgow Copper Intake Study Group: TS Wilson, (chairman), JC Sherlock (director of study). Members: G Chittick, HT McIntosh, R Paterson, AP Robertson, S Salim, A Vardag, W Daoud, GI Forbes, A Green, W Richards, GC Arneil, F Cockburn, RW Logan, RT Leslie, EM Gibb, MM Miller, J Scott, J Farquharson, F MacMillan, J Warren, A Burrell, S Davis.
}

These infants were either breast fed or fed one of two milk formulas supplying copper at different concentrations, one at the upper end of the range of normal concentration and the other at the lower end of the range. The relation between the type of milk and growth and the effect of the type of milk on the concentrations of plasma copper and zinc are examined.

\section{Patients and methods}

Mothers and infants. Mothers attending prenatal clinics in a large housing scheme and in the Queen Mother's Maternity Hospital, Glasgow, volunteered to take part after a full explanation of the aims of the study.

One hundred and four infants born at term with a normal birth weight $(>2500 \mathrm{~g})$ and 41 low birthweight $(<2500 \mathrm{~g})$ infants completed the study. Infants within each group were randomly allocated to a 'low copper' or 'high copper' formula except when the mother chose to breast feed her infant. These data, gender, birth weights, gestational ages, and feeding groups are shown in Table 1. The gestational age range of the low birthweight infants was $32-40$ weeks. The birth weights of seven low birthweight infants lay between the 10th and 20th 
Table 1 Clinical details of groups of low $(<2500 \mathrm{~g})$ and normal $(>2500 \mathrm{~g})$ birthweight infants fed human milk or high or low copper milk formula

\begin{tabular}{|c|c|c|c|c|c|c|c|c|c|c|}
\hline & \multirow[t]{3}{*}{ Sex } & \multicolumn{9}{|c|}{ Group } \\
\hline & & \multicolumn{3}{|c|}{ Breast fed } & \multicolumn{3}{|c|}{ Low copper } & \multicolumn{3}{|c|}{ High copper } \\
\hline & & $n$ & Mean $(S D)$ & Range & $n$ & Mean $(S D)$ & Range & $n$ & Mean (SD) & Range \\
\hline \multicolumn{11}{|c|}{ Normal birthweight infants } \\
\hline \multirow[t]{2}{*}{ Birth weight $(\mathrm{g})$} & $\mathbf{M}$ & 14 & $3885(593)$ & $3240-5000)$ & 23 & $3494(388)$ & $2800-4380$ & 14 & $3522(325)$ & $291(1-4120$ \\
\hline & $\mathrm{F}$ & 20 & $3511(361)$ & $2610-4280$ & 18 & $3340(371)$ & $2560-4220$ & 15 & $3550(457)$ & 290()$-4700$ \\
\hline \multirow[t]{2}{*}{ Gestation (wks) } & $\mathbf{M}$ & 14 & $40 \cdot 5(0 \cdot 8)$ & $40-42$ & 23 & $40 \cdot 0(0 \cdot 8)$ & $38-41$ & 14 & $39 \cdot 9(1 \cdot 0)$ & $37-42$ \\
\hline & $\mathrm{F}$ & 20 & $39 \cdot 8(0 \cdot 8)$ & $38-41$ & 18 & $39 \cdot 8(0 \cdot 9)$ & $37-41$ & 15 & $4(0 \cdot 1(0 \cdot 5)$ & $39-42$ \\
\hline \multicolumn{11}{|c|}{ Low birthweight infants } \\
\hline \multirow[t]{2}{*}{ Birth weight $(\mathrm{g})$} & $\mathbf{M}$ & 4 & $2145(488)$ & $1800-2499$ & 6 & $2054(455)$ & $1430-2460$ & 10 & $2246(182)$ & $1940-2490$ \\
\hline & $\mathrm{F}$ & 4 & $2250(195)$ & $1970-2450$ & 10 & $2228(293)$ & $1550-2490$ & 7 & $2152(371)$ & $1490-2499$ \\
\hline \multirow[t]{2}{*}{ Gestation (wks) } & $\mathbf{M}$ & 4 & $38 \cdot 5(2 \cdot 4)$ & $35-40$ & 6 & $35 \cdot 9(2 \cdot 5)$ & $33-40$ & 10 & $36.6(2 \cdot 0)$ & $33-40$ \\
\hline & $\mathrm{F}$ & 4 & $36 \cdot 8(3 \cdot 4)$ & $32-40$ & 10 & $36 \cdot 8(2 \cdot 5)$ & $33-40$ & 7 & $37 \cdot 3(2 \cdot 9)$ & $33-40$ \\
\hline
\end{tabular}

centiles for Scottish infants, ${ }^{2}$ and the remaining 34 were below the 10th centile.

Of the three boys in the group between the 10th and 20 centiles, two were in the high copper group and one in the low copper group. Of the four girls in this centile group, one was in the high copper group, two in the low copper group, and one was breast fed. None of the infants required assisted ventilation or suffered appreciable neonatal disease that might have interfered with early weight gain. From birth onwards the infants were fed on demand until satisfied.

During a period of seven days preceding the 8-10 week blood samples, the mother kept a diary recording the volumes of infant formula consumed during each day. The postconceptional ages during which the dietary intakes were recorded ranged from 40 to 49 weeks (median 47.8 weeks) and the postnatal ages from 8 to 10 weeks (median 9.2 weeks).

Milks. The low copper milk was an Ostermilk Complete Formula (Farley Health Products) in standard use until 1983, containing $0.5 \mu \mathrm{mol} / \mathrm{l}$ $(3 \mu \mathrm{g} / 100 \mathrm{ml})$ of copper. The high copper milk was the same basic formula but with a copper content of $6.3 \mu \mathrm{mol} / \mathrm{l}(40 \mu \mathrm{g} / 100 \mathrm{ml})$, which has been available since 1983.

The zinc concentration in both formulas was 78 $\mu \mathrm{mol} / \mathrm{l}(510 \mu \mathrm{g} / 100 \mathrm{ml})$. Analysis of the mature human milk obtained by manual expression at 6 to 9 weeks from mothers of 29 normal birthweight and seven low birthweight infants gave a mean copper concentration of $5.8 \mu \mathrm{mol} / \mathrm{l}(37 \mu \mathrm{g} / 100 \mathrm{ml})$ and a mean zinc concentration of $27.1 \mu \mathrm{mol} / \mathrm{l}(177 \mu \mathrm{g} /$ $100 \mathrm{ml}$ ).

Samples for analyses. Venous blood samples were obtained from mothers at 28 weeks' gestation, at the birth of the infant, and at 8-10 weeks after the birth. A heel prick blood sample was obtained from the infant 8-10 weeks after birth. Where practicable, samples of cord blood and amniotic fluid were also collected. Blood samples were analysed for plasma copper and plasma and leucocyte zinc concentrations. Infant hair was obtained at 8-10 weeks for determination of copper content. Amniotic fluid was centrifuged immediately after collection and the supernatant later analysed for total copper and total zinc concentrations.

Biochemical analysis. Plasma copper and zinc analyses were performed using atomic absorption equipment by the procedure detailed in a previous publication. $^{3}$

In the case of copper, within and between batch coefficients of variation at a plasma concentration of $3.4 \mu \mathrm{mol} / 1$ were $8.6 \%$ and $10 \%$, respectively. At a concentration of $13.4 \mu \mathrm{mol} / \mathrm{l}$ the corresponding figures were $2.9 \%$ and $3.5 \%$. The sensitivity of the method for $95 \%$ confidence limits was $0.3 \mu \mathrm{mol} / \mathrm{l}$. In the case of zinc, the intrabatch and interbatch coefficients of variation were $9.8 \%$ and $11.4 \%$ at $4.4 \mu \mathrm{mol} / \mathrm{l}$ and $3 \%$ and $3.8 \%$ at $19.2 \mu \mathrm{mol} / \mathrm{l}$, and sensitivity of the method was $0.5 \mu \mathrm{mol} / \mathrm{l}$.

For measurements of both copper and zinc, quality control was effected by incorporating specimens from the Guildford quality control scheme in each batch of assays. No analysis was accepted where the result for control serum samples differed by more than one standard deviation from the mean.

Whole blood was employed for measurement of lead. Preparation of leucocyte pellets for determination of zinc was undertaken, using lithium heparinised venous whole blood, dextran separation of leucocytes, centrifugation, and repeated washing. The protein determination was by the Lowry technique. 
Analysis of hair copper was by atomic absorption spectrophotometry, which was also employed for the determination of the copper and zinc concentrations in breast milk and amniotic fluid.

Growth measurements. Accurate measurements of weight, length, arm circumference, occipitofrontal circumference, and subscapular and triceps skinfold thicknesses were obtained at birth and at 8-10 weeks after birth. Crown-heel length was measured using a Holtain neonatometer, infants were weighed on standard beam scales, occipitofrontal circumferences and mid-arm circumferences were measured to the succeeding millimetre using a paper tape, and skinfold thicknesses were measured using Holtain callipers (British Indicators Ltd).

\section{Results}

Infants of low birth weight and on the low copper diet ingested $0.08 \mu \mathrm{mol}(4.9 \mu \mathrm{g}) / \mathrm{kg}$ body weight per day of copper, while those on the high copper diet ingested $1.02 \mu \mathrm{mol}(65 \mu \mathrm{g}) / \mathrm{kg}$ body weight per day. In the normal birthweight infants the corresponding values for those fed the low and high copper diets were $0.07 \mu \mathrm{mol}(4.4 \mu \mathrm{g}) / \mathrm{kg}$ body weight per day and $0.92 \mu \mathrm{mol}(58 \mu \mathrm{g}) / \mathrm{kg}$ body weight per day.

Breast milk analyses showed that the breast fed infants took in $0.58 \mu \mathrm{mol}(37 \mu \mathrm{g})$ of copper and 2.71 $\mu \mathrm{mol}(177 \mu \mathrm{g})$ of zinc for every $100 \mathrm{ml}$ ingested, giving a copper:zinc ratio in the breast fed infants diet of $0 \cdot 21$. The copper:zinc ratio for infants fed low copper formula was 0.006 and for those fed the high copper formula was $0 \cdot 08$.

Concentrations of copper and zinc in the venous blood plasma from the mothers at 28 weeks' gestation, at birth, and at 8-10 weeks after birth, together with concentrations in the umbilical venous plasma and infant capillary plasma at 8-10 weeks after birth are shown in Table 2 . There was no significant correlation between copper or zinc concentrations measured in the three maternal plasma samples. There was a significant correlation between copper concentrations in maternal plasma taken at the time of birth and in the umbilical venous plasma. Zinc concentrations showed a similar correlation. The appropriate values for plasma copper concentrations were $r=0.31$ and $p<0.001$ and for plasma zinc concentrations were $r=0 \cdot 17$ and $\mathrm{p}<0.001$.

The mean plasma zinc concentrations in maternal blood were not significantly different between 28 weeks' gestation and delivery but increased significantly after the birth of the infant. Similarly, the mean plasma copper concentration in maternal blood at 28 weeks' gestation and at birth were not significantly different, but after birth the concentrations fell to normal values. Concentrations of copper and zinc in the infant's plasma 8-10 weeks after birth did not correlate with any of the other measurements of copper and zinc.

Amniotic fluid copper concentrations obtained from six low birthweight infant deliveries ranged from 1.6 to 16.5 (mean (SD) $-8.5(6.3)$ ) $\mu \mathrm{mol} / \mathrm{l}$ and zinc from 1.5 to $14.2(7.3(4.7)) \mu \mathrm{mol} / \mathrm{l}$. Values for copper obtained from amniotic fluid samples from 24 normal birthweight infants ranged from 0.5 to $14.0(3 \cdot 2(3 \cdot 7)) \mu \mathrm{mol} / \mathrm{l}$ and for zinc from 0.3 to 30.6 $(8.6(9.0)) \mu \mathrm{mol} / \mathrm{l}$.

All plasma copper and zinc concentrations displayed essentially normal distributions. In the case of amniotic fluid, copper and zinc concentrations and leucocyte zinc concentrations log-normal distributions obtained.

Table 2 Concentrations of zinc and copper in maternal venous blood plasma at 28 weeks' gestation, at birth, and at 8-10 weeks after birth, infant umbilical venous blood, and infant capillary blood at 8-10 weeks after birth in low $(<2500 \mathrm{~g})$ and normal $(>2500 \mathrm{~g})$ birthweight infants

\begin{tabular}{|c|c|c|c|c|c|c|c|c|c|c|c|c|}
\hline \multirow[t]{3}{*}{ Plasma samples } & \multicolumn{6}{|c|}{ Zinc ( $\mu$ molll) } & \multicolumn{6}{|c|}{ Copper ( $\mu \mathrm{mol} / \mathrm{l})$} \\
\hline & \multicolumn{3}{|c|}{ Low birthweight } & \multicolumn{3}{|c|}{ Normal birthweight } & \multicolumn{3}{|c|}{ Low birthweight } & \multicolumn{3}{|c|}{ Normal birthweight } \\
\hline & $n$ & Mean & $(S D)$ & $n$ & Mean & $(S D)$ & $n$ & Mean & $(S D)$ & $n$ & Mean & $(S D)$ \\
\hline \multicolumn{13}{|l|}{$\begin{array}{l}\text { Maternal: } \\
\text { At } 28 \text { weeks }\end{array}$} \\
\hline gestation & 22 & $13 \cdot 7$ & $(2 \cdot 8)^{*}$ & 99 & $12 \cdot 0$ & $(3 \cdot 2)^{*}$ & 11 & $30 \cdot 5$ & $(8 \cdot 7)$ & 101 & $30 \cdot 5$ & $(6 \cdot 0)$ \\
\hline $\begin{array}{l}\text { At birth } \\
\text { At } 8-10 \text { weeks }\end{array}$ & 12 & $13 \cdot 5$ & $(2 \cdot 8)^{*}$ & 89 & $11 \cdot 1$ & $(3 \cdot 2)^{*}$ & 23 & $34 \cdot 2$ & $(8 \cdot 5)$ & 89 & $31 \cdot 2$ & $(7 \cdot 9)$ \\
\hline after birth & 30 & $16 \cdot 8$ & $\left(3 \cdot(0)^{*}\right.$ & 96 & $15 \cdot 3$ & $(3 \cdot 1)^{*}$ & 32 & $20 \cdot 5$ & $(7 \cdot 9)$ & 97 & $20 \cdot 5$ & $(6 \cdot 1)$ \\
\hline Umbilical venous blood & 24 & $20 \cdot 8$ & $(3 \cdot 8)^{*}$ & 72 & $18 \cdot 8$ & $(4 \cdot 9)^{*}$ & 32 & $6 \cdot 9$ & $(3 \cdot 6)$ & 75 & $6 \cdot 9$ & $(2 \cdot 5)$ \\
\hline $\begin{array}{l}\text { Infant capillary blood } \\
\text { at } 8-10 \text { weeks after } \\
\text { birth }\end{array}$ & 30 & $16 \cdot 1$ & $(4 \cdot 6)$ & 83 & $15 \cdot 5$ & $(5 \cdot 5)$ & 32 & $11 \cdot 6$ & $(4 \cdot 7)$ & 95 & $11 \cdot 8$ & $(3 \cdot 0)$ \\
\hline
\end{tabular}

${ }^{*}$ Difference between pairs of means significant at $\mathrm{p}<0.05$. 
Table 3 shows plasma and leucocyte zinc concentrations in mothers before, at, and after delivery and in the infants at delivery in low birthweight and normal birthweight groups. When the ratios of plasma zinc:leucocyte zinc in maternal blood at delivery were examined in relation to infant birth weight there was a significant negative correlation $(\mathrm{r}=-0.38 ;$ y $\quad($ ratio $)=2.86-0.47 \times($ birth weight $)$, $\mathrm{n}=68)$.

Comparison of values in low and normal birth weight infants. There were no significant differences between the mean copper concentrations in the blood of mothers having low and normal birthweight infants at any of the sampling times. Similarly, there were no significant differences in the umbilical venous plasma copper concentrations or in the infants' plasma concentrations at $8-10$ weeks. There was no difference in the mean plasma zinc concentrations for low and normal birthweight infants at 8-10 weeks. There were significant differences in the mean plasma zinc concentrations between the mothers of low and normal birthweight infants at 28 weeks' gestation, at delivery, and at 8-10 weeks after birth; in each instance the higher zinc concentrations were in the low birthweight group. The umbilical venous plasma zinc concentrations were significantly higher in the low birthweight than in the normal birthweight infants.

Considering the four pairs of means together and bearing in mind that the serial zinc concentrations are not correlated, the results indicate that mothers

Table 3 Zinc concentrations in maternal venous plasma (umolll) and leucocytes ( $\mathrm{mg} / \mathrm{kg}$ protein) at 28 weeks' gestation, at delivery, and $8-10$ weeks after delivery in mothers of low $(<2500 \mathrm{~g})$ and normal $(>2500 \mathrm{~g})$ birthweight infants and in infant umbilical venous blood

\begin{tabular}{|c|c|c|c|c|c|c|c|c|c|}
\hline & \multirow{2}{*}{$\begin{array}{l}\text { Blood } \\
\text { sample }\end{array}$} & \multicolumn{4}{|c|}{ Low birthweight } & \multicolumn{4}{|c|}{ Normal birthweight } \\
\hline & & $n$ & Mean & $(S D)$ & Range & $n$ & Mean & $(S D)$ & Range \\
\hline \multicolumn{10}{|l|}{ Maternal blood: } \\
\hline \multirow[t]{2}{*}{ At 28 weeks' gestation } & Plasma & 22 & $13 \cdot 7^{*}$ & $(2 \cdot 8)$ & $8 \cdot 6-19 \cdot 7$ & 99 & $12 \cdot()^{*}$ & $(3 \cdot 2)$ & $2 \cdot 3-23 \cdot 3$ \\
\hline & Leucocyte & 4 & $61 \cdot 2$ & $(30 \cdot 4)$ & $35-90$ & 68 & $107 \cdot 0$ & $(45 \cdot 2)$ & $40-275$ \\
\hline \multirow[t]{2}{*}{ At delivery } & Plasma & 12 & $13 \cdot 5^{*}$ & $(2 \cdot 8)$ & $6 \cdot 7-17 \cdot 0$ & 89 & $11 \cdot 1^{*}$ & $(3 \cdot 1)$ & $0.92-19.4$ \\
\hline & Leucocyte & 17 & $58 \cdot 8$ & $(32 \cdot 8)$ & $25-145$ & 68 & $72 \cdot 8$ & $(31 \cdot 7)$ & $20-210$ \\
\hline \multirow{3}{*}{$\begin{array}{l}\text { At } 8-10 \text { weeks } \\
\text { after delivery }\end{array}$} & & & & & & & & & \\
\hline & Plasma & 30 & $16 \cdot 8^{*}$ & $(3 \cdot 0)$ & $11 \cdot 3-24 \cdot 8$ & 96 & $15 \cdot 3^{*}$ & $(3 \cdot 1)$ & $4 \cdot 3-29 \cdot 4$ \\
\hline & Leucocyte & 26 & $135 \cdot()$ & $(64 \cdot 8)$ & $60-335$ & 67 & $171 \cdot 0$ & $(71 \cdot 5)$ & $50-380$ \\
\hline \multirow{3}{*}{$\begin{array}{l}\text { Infant umbilical } \\
\text { venous blood at } \\
\text { delivery }\end{array}$} & & & & & & & & & \\
\hline & Plasma & 24 & $20 \cdot 8^{*}$ & $(3 \cdot 8)$ & $11 \cdot 8-25 \cdot 7$ & 72 & $18 \cdot 8^{*}$ & $(4.9)$ & $9 \cdot 2-32 \cdot 0$ \\
\hline & Leucocyte & 6 & $168 \cdot 0$ & $(39 \cdot 8)$ & $120-240$ & 27 & $116 \cdot 0$ & $(55 \cdot 0)$ & $45-245$ \\
\hline
\end{tabular}

${ }^{*}$ Difference between pairs of means significant at $\mathrm{p}<0 \cdot 05$.

Table 4 Concentrations of copper and zinc (umolll) in maternal venous blood plasma at 28 weeks' gestation, at birth, and at 8-10 weeks after birth and in infant umbilical venous blood and capillary blood at 8-10 weeks after birth related to feeding group

\begin{tabular}{|c|c|c|c|c|c|c|c|c|c|c|}
\hline \multirow[t]{3}{*}{ Blood sample } & & \multicolumn{9}{|c|}{ Feeding group } \\
\hline & & \multicolumn{3}{|c|}{ Breast } & \multicolumn{3}{|c|}{ Low copper } & \multicolumn{3}{|c|}{ High copper } \\
\hline & & $n$ & Mean & $(S D)$ & $n$ & Mean & $(S D)$ & $n$ & Mean & $(S D)$ \\
\hline \multicolumn{11}{|l|}{ Maternal blood: } \\
\hline \multirow[t]{2}{*}{ At 28 weeks' gestation } & Copper & 30 & $28 \cdot 3$ & $(6 \cdot 8)$ & 38 & $31 \cdot 5$ & $(6 \cdot 6)$ & 30 & $30 \cdot 2$ & $(5 \cdot 7)$ \\
\hline & Zinc & 36 & $12 \cdot 7$ & $(3 \cdot 7)$ & 39 & 11.9 & $(3 \cdot 5)$ & 31 & $12 \cdot 2$ & $(2 \cdot 3)$ \\
\hline \multirow[t]{2}{*}{ At delivery } & Copper & 33 & $29 \cdot 9$ & $(8 \cdot 2)$ & 34 & $32 \cdot 9$ & $(9 \cdot 6)$ & 32 & $31 \cdot 8$ & $(6 \cdot 5)$ \\
\hline & Zinc & 28 & $11 \cdot 0$ & $(3 \cdot 7)$ & 31 & $10 \cdot 7$ & $(3 \cdot 2)$ & 28 & $12 \cdot 4$ & $(3 \cdot 1)$ \\
\hline \multirow{3}{*}{$\begin{array}{l}\text { At } 8-10 \text { weeks after } \\
\text { delivery }\end{array}$} & & & & & & & & & & \\
\hline & Copper & 35 & $17 \cdot 5$ & $(3 \cdot 6)$ & 41 & $21 \cdot 7$ & $(6 \cdot 9)$ & 35 & $20 \cdot 9$ & $(7 \cdot 4)$ \\
\hline & Zinc & 34 & $15 \cdot 6$ & $(3 \cdot 5)$ & 40 & $15 \cdot 8$ & $(3 \cdot 7)$ & 35 & $15 \cdot 3$ & $(2 \cdot 4)$ \\
\hline \multirow[t]{2}{*}{ Umbilical venous blood } & Copper & 30 & 6.9 & $(3 \cdot 1)$ & 36 & 6.6 & $(3 \cdot 0)$ & 28 & $7 \cdot 2$ & $(2 \cdot 8)$ \\
\hline & Zinc & 28 & $18 \cdot 8$ & $(5.5)$ & 31 & $18 \cdot 7$ & $(4 \cdot 6)$ & 25 & $19 \cdot 7$ & $(3 \cdot 8)$ \\
\hline \multicolumn{11}{|l|}{ Infant's blood at } \\
\hline \multirow[t]{2}{*}{$8-10$ weeks after birth } & Copper & 35 & $12 \cdot 4$ & $(3 \cdot 5)$ & 41 & $11 \cdot 2$ & $(3 \cdot 1)$ & 33 & $11 \cdot 8$ & $(4 \cdot 2)$ \\
\hline & Zinc & 30 & $17 \cdot 6$ & $(5 \cdot 8)^{*}$ & 38 & 15.8 & $(4 \cdot 7)$ & 30 & $13 \cdot 8$ & $(4 \cdot 3)^{*}$ \\
\hline
\end{tabular}

*Difference between means significant at $p<0 \cdot(0) 5$. 
1072 Salim, Farquharson, Arneil, Cockburn, Forbes, Logan, Sherlock, and Wilson

who have low birthweight infants tend to have higher plasma zinc concentrations than those who have normal birthweight infants.

Effect of the feeding regimen. There were no significant differences in umbilical venous plasma copper concentrations between low and normal birthweight infants; consequently, the data for these two groups have been combined when comparing the plasma copper concentrations obtained from infants on the three feeding regimens (Table 4).

Mothers who breast fed their infants tended to have lower plasma copper concentrations than the other mothers; the differences, however, between the mean concentrations at 28 weeks' gestation, at birth, and at 8-10 weeks after birth were not significant. The mean umbilical venous plasma copper concentrations were almost identical for the three groups of infants. Breast fed infants aged 8-10 weeks had the highest mean plasma copper concentration, the infants in the low copper group the lowest, and the infants in the high copper group an intermediate value. The difference between the mean plasma copper concentration for the infants who were breast fed and the infants in the low copper group did not reach significance at the $5 \%$ level $(p=0 \cdot 086)$. The plasma zinc concentrations in the breast fed infants were also greater than the values found in the formula fed infants, and it is noticeable that the lowest mean plasma zinc concen-
Table 5 Copper:zinc concentration (molar ratios) in diets and in plasma of infants after 8 weeks being breast fed or fed on a high or low copper content milk

\begin{tabular}{lll}
\hline Feeding group & Copper:zinc ratio & \\
\cline { 2 - 3 } & Diet & Plasma \\
\hline Breast fed & 0.21 & 0.70 \\
Low copper formula & 0.0166 & 0.71 \\
High copper formula & $(1.08$ & 0.86 \\
\hline
\end{tabular}

tration was found in the infants in the high copper group $(p=<0.005)$ (Table 4$)$.

The mean plasma copper:zinc ratios were similar despite wide differences in the dietary ratios of copper and zinc in the three feeding regimens. Table 5 gives the increments between birth and 8 weeks in the low and normal birthweight infants fed their mother's breast milk or high or low copper content formulas.

Infant growth. Rates of growth of the infants during the first eight weeks after birth were calculated as the arithmetic difference of their measurements taken at birth and at 8 weeks; rates of growth were ascertained for each of the six measurements weight, length, head circumference, arm circumference, and triceps and subscapular skinfold thicknesses (Table 6).

Analyses of variance were carried out for normal

Table 6 Growth increments between birth and 8 weeks in low $(<2500 \mathrm{~g})$ and normal $(>2500 \mathrm{~g})$ birthweight infants fed low or high copper content formulas or human milk

\begin{tabular}{|c|c|c|c|c|c|c|c|}
\hline & \multirow[t]{2}{*}{ Feed } & \multicolumn{3}{|c|}{ Low birthweight } & \multicolumn{3}{|c|}{ Normal hirthweight } \\
\hline & & $n$ & Increment & $\begin{array}{l}\text { SD } \\
\text { (pooled) }\end{array}$ & $n$ & Increment & $\begin{array}{l}S D \\
\text { (pooled) }\end{array}$ \\
\hline Weight (kg) & $\begin{array}{l}\text { BF } \\
\text { LC } \\
\text { HC }\end{array}$ & $\begin{array}{r}8 \\
16 \\
15\end{array}$ & $\left.\begin{array}{l}1.861 \\
1.831 \\
1.925\end{array}\right\}$ & 0.387 & $\begin{array}{l}33 \\
38 \\
28\end{array}$ & $\left.\begin{array}{l}1.90(0) \\
1.806 \\
1.656\end{array}\right\}$ & 0.555 \\
\hline Length $(\mathrm{cm})$ & $\begin{array}{l}\mathrm{BF} \\
\mathrm{LC} \\
\mathrm{HC}\end{array}$ & $\begin{array}{r}8 \\
16 \\
15\end{array}$ & $\left.\begin{array}{l}7 \cdot 98 \\
9 \cdot 46 \\
9 \cdot 07\end{array}\right\}$ & $2 \cdot 11$ & $\begin{array}{l}33 \\
38 \\
28\end{array}$ & $\left.\begin{array}{l}8 \cdot(12 \\
8 \cdot 68 \\
8 \cdot 87\end{array}\right\}$ & 1.79 \\
\hline $\begin{array}{l}\text { Occipitofrontal } \\
\text { circumference }(\mathrm{cm})\end{array}$ & $\begin{array}{l}\mathrm{BF} \\
\mathrm{LC} \\
\mathrm{HC}\end{array}$ & $\begin{array}{r}8 \\
16 \\
15\end{array}$ & $\left.\begin{array}{l}5 \cdot 388 \\
6 \cdot 112 \\
5 \cdot 707\end{array}\right\}$ & $1 \cdot 104$ & $\begin{array}{l}33 \\
38 \\
28\end{array}$ & $\left.\begin{array}{l}4 \cdot 741 \\
4 \cdot 689 \\
4 \cdot 654\end{array}\right\}$ & $1 \cdot 091$ \\
\hline Arm circumference $(\mathrm{cm})$ & $\begin{array}{l}\text { BF } \\
\text { LC } \\
\text { HC }\end{array}$ & $\begin{array}{r}8 \\
16 \\
15\end{array}$ & $\left.\begin{array}{l}2 \cdot 413 \\
2 \cdot 881 \\
3 \cdot 153\end{array}\right\}$ & $1 \cdot 050$ & $\begin{array}{l}33 \\
38 \\
28\end{array}$ & $\left.\begin{array}{l}1.657 \\
1.454 \\
1 \cdot 129\end{array}\right\}$ & $1 \cdot 097$ \\
\hline Triceps skinfold (mm) & $\begin{array}{l}\text { BF } \\
\text { LC } \\
\text { HC }\end{array}$ & $\begin{array}{r}8 \\
16 \\
15\end{array}$ & $\left.\begin{array}{l}3 \cdot 475 \\
3 \cdot 781 \\
3 \cdot 433\end{array}\right\}$ & 1.611 & $\begin{array}{l}33 \\
38 \\
28\end{array}$ & $\left.\begin{array}{l}3.794 \\
2 \cdot 921 \\
2 \cdot 268\end{array}\right\}$ & $1 \cdot 748$ \\
\hline Subscapular skinfold ( $\mathrm{mm}$ ) & $\begin{array}{l}\text { BF } \\
\text { LC } \\
\text { HC }\end{array}$ & $\begin{array}{r}8 \\
16 \\
15\end{array}$ & $\left.\begin{array}{l}3 \cdot 5(x) \\
3 \cdot 462 \\
2 \cdot 640\end{array}\right\}$ & 1.276 & $\begin{array}{l}33 \\
38 \\
28\end{array}$ & $\left.\begin{array}{l}3 \cdot 152 \\
2 \cdot 487 \\
2 \cdot 121\end{array}\right\}$ & 1.770 \\
\hline
\end{tabular}

$\mathrm{BF}=$ Breast fed: $\mathrm{LC}=$ low copper formula: $\mathrm{HC}=$ high copper formula. 
and low birthweight categories and for each of the six measurements in each of the three feed categories. No consistent dietary effect was found except for a greater increase in triceps skinfold thickness in normal birthweight breast fed infants (mean increase in triceps skinfold thickness for infants who were breast fed was $3.8 \mathrm{~mm}$, for infants in the low copper group was $2.9 \mathrm{~mm}$, and for infants in the high copper group was $2.3 \mathrm{~mm}$ ). The triceps skinfold thicknesses of the infants fed the high and low copper content formulas did not differ significantly from each other. The difference between the breast fed and formula fed infants was significant at a $1 \%$ level. Despite this, the difference may be unremarkable; with so many comparisons being made it is not surprising that one of them achieved significance.

A series of 20 tables giving fuller information about infant growth characteristics as well as the full results of biochemical analyses of concentrations of maternal and infant plasma copper and zinc, maternal and umbilical venous leucocyte zinc, blood lead, amniotic fluid copper and zinc, breast milk copper and zinc, and infant's hair copper at 8 weeks can be obtained.*

\section{Discussion}

The dietary requirement of the fetus for copper must be met from the maternal diet and maternal tissue reserves, and in turn this might influence the copper reserves in the preterm or term newborn. Bioavailability of copper depends on various factors, including concentrations and distribution of copper binding and carrying proteins and concentrations of other dietary constituents, including phytate and zinc.

Sturgeon and Brubaker described the typical clinical features of copper deficiency in infancy in $1956,{ }^{4}$ and Al-Rashid and Spangler described an infant of low birth weight who developed oedema, anaemia, bone disease, and recurrent apnoea associated with a low plasma copper concentration in $1971 .{ }^{5}$ Both studies showed that these abnormalities could be corrected by giving copper supplements. Since then numerous reports of isolated copper deficiency in infants have been published. ${ }^{36-8}$ Copper deficiency in preterm low birthweight infants has already been reported from Glasgow and a previous dietary survey showed very low copper intakes during infancy.

In the present study there was no obvious

${ }^{*}$ Dr T S Wilson, Community Medicine Specialist, Greater Glasgow Health Board, 225 Bath Street, Glasgow G2 4JT, Scotland. problem shown during the first eight weeks of life related to a copper intake of $0.5 \mu \mathrm{mol} / 1$ of formula compared with an intake of $6 \cdot 3 \mu \mathrm{mol} / \mathrm{l}$, even in low birthweight infants.

Fetal copper metabolism differs substantially from that of the older infant and child. At birth the liver copper concentrations are five to 10 times greater than in the adult, ${ }^{9}$ but in spite of this the plasma concentrations of copper and the copper carrying caeruloplasmin are much lower than in the older infant and child. In fetal and neonatal liver biopsy specimens the excess copper can be shown histochemically, as can a copper associated protein not demonstrable in the more mature liver. ${ }^{10}$ This copper can be located within electron dense lysosomes with a specific neonatal carrier protein believed to be localised to lysosomes rather than mitochondria. ${ }^{11}$ Although the liver copper concentrations are within the range associated with homozygous Wilson's disease, there is no biochemical, structural, or ultrastructural evidence of copper toxicity and the copper is complexed and packaged in membrane bound lysosomes. ${ }^{10}$ At about 3-4 months of age both liver copper and plasma concentrations of copper and caeruloplasmin approach the adult range. ${ }^{12}$

Sutton et al showed that poor growth, peripheral oedema, osteoporosis, neutropenia, anaemia, and apnoea can occur in copper deficient infants with birth weights less than $1500 \mathrm{~g}^{3}$. At such very low birth weights reserves of liver copper are minimal and it is not surprising that dietary deficiencies can result in clinical abnormalities. In the older infants in this study, irrespective of birth weight, there was no evidence of clinical abnormality or disturbance in growth, even though the highest copper intake was still below the WHO minimum recommended intake.

Mean haemoglobin concentrations and packed cell volumes at 8-10 weeks of age were not significantly different between the six groups of infants in this study. Evidently, copper reserves and copper intakes were adequate to maintain haemoglobin synthesis in spite of intakes below the recommended minimum.

Whether there will be long term effects on body tissues from such low copper intakes is unknown. Copper is present in many intracellular enzymes, and reduced function of these in the copper deficient state may interfere with collagen synthesis through a deficiency of lysyl oxidase activity and poor quality elastin. The function of the copper dependent superoxide group of enzymes is to protect the cell from the superoxide radical, and failure of antioxidant mechanisms has been reputed to increase the rate at which tissues age. 
Although the dietary ratios of copper and zinc in the breast fed infants and infants in the low copper group were very different, mean plasma copper:zinc ratios were similar. Infants fed high copper formula had a greater mean plasma copper:zinc ratio than breast fed infants or infants fed low copper formula. Copper and zinc are biological antagonists, and dietary supplementation with zinc in man reduces the copper:zinc ratio in plasma. ${ }^{13} 14$ In rats reduced copper:zinc ratios were associated with hypercholesterolaemia, ${ }^{15}$ but recent workers have failed to confirm this. ${ }^{16}$

Influence of maternal intakes of copper and zinc during pregnancy on the growth rates of the fetus have been examined. ${ }^{17-21}$ There was no obvious correlation between the amniotic fluid copper and zinc concentrations and infant birth weight or gestational age.

The maternal plasma copper and zinc concentrations and maternal white blood cell zinc concentrations in this study also failed to show any direct correlation with infant birth weight. Mean white cell zinc concentration in mothers with light for dates, growth retarded infants was lower than in mothers of appropriately grown preterm and term normal birthweight infants, but these differences failed to reach significance. This might reflect the small numbers studied.

The data indicate that ratios of maternal venous plasma zinc to leucocyte zinc at delivery are related to infant birth weight. Further investigation of the association of a fairly high plasma and low leucocyte zinc as a possible index of maternal zinc deficiency and impaired fetal growth is warranted.

Dietary zinc deficiency has been postulated in young women who are not pregnant in West Scotland. ${ }^{22}$ The present study did not examine maternal intake but confirms the high plasma zinc concentrations reported in mothers of low birthweight infants during pregnancy. 2324 No overt pre-eclampsia occurred in our mothers of low birthweight infants. These same mothers had lower mean white blood cell zinc concentrations than mothers of normal birthweight infants at 28 weeks' gestation, at delivery, and at two months post partum. This might be explained by a relative reduction in zinc binding substances within leucocytes and an increase in plasma zinc binders in the blood of mothers of low birthweight infants but cannot be explained on the basis of plasma volume differences ${ }^{20}$ or free zinc concentrations. ${ }^{25}$ These important findings clearly justify further investigation into the role of zinc in fetal and infant development.

The infants studied had copper intakes below the minimum WHO recommendations without obvious physical or biochemical problems at the age of 2 months. With present milk formulas it is unlikely that WHO minimum recommendations for copper intake can be achieved. Either there is a subclinical copper deficiency state in infants or the WHO recommendations are in error. If manufacturers increase only the copper content in their formulas to achieve the WHO recommendations this could critically reduce the bioavailability of zinc in their formulas. Although the infants in this study were all healthy, infection or other illness might precipitate a problem associated with 'borderline' copper intakes.

The extraordinary adaptability of the human newborn infant to wide variation in copper intake and in copper:zinc ratio intake is noted. Whether there is any long term consequence of such adaptation remains to be proved.

We gratefully acknowledge the Ministry of Agriculture, Fisheries and Food for funding these investigations and the Ministry of Agriculture. Fisheries and Food Laboratory at Norwich for the analyses of copper and zinc in the breast milk and infant formulas. Farley Health Products Limited generously provided the milk formulas and additional funding to enable the follow up component of the study and we thank them for their support. We also acknowledge our debt to Dr T L Turner and the paediatric staff. Professor C R Whitfield and the obstetric staff, and midwives in the labour ward and clinics of the Queen Mother's Maternity Hospital and the Glasgow mothers, without whose cooperation this study could not have been undertaken.

\section{References}

I The Glasgow Duplicate Diet Study (1979/80). A joint survey for the Department of the Environment and the Ministry of Agriculture, Fisheries and Food. London: HMSO, 1982:1-34. (Department of the Environment Pollution Report No 11.)

2 Information Services Division. Scottish Health Service Common Services Agency. Birthweight, head circumference and length by gestational age. Scotland 1973-1979. Glasgow: SHSCSA. 1981:1-11.

${ }^{3}$ Sutton AM, Harvie A, Cockburn F, Farquharson J, Logan RW. Copper deficiency in the preterm infant of very low birthweight. Arch Dis Child 1985;60:644-51.

+ Sturgeon P. Brubaker C. Copper deficiency in infants. Am J Dis Child 1956:92:254-65.

5 Al-Rashid RA, Spangler J. Neonatal copper deficiency. $N$ Engl J Med 1971:285:841-3

6 Ashkenazi A, Levin S, Djaldeth M, Fishel E, Benvisti D. The syndrome of neonatal copper deficiency. Pediatrics 1973:52:525-33.

7 Heller RM, Kirchner SG, O'Neil JA. et al. Skeletal changes of copper deficiency in infants receiving prolonged parenteral nutrition. J Pediatr 1978;92:947-9.

` Gruncbaum M. Horodmceanu C, Steinherz R. The radiographic manifestations of bone changes in copper deficiency. Pediatr Radiol 1980;9:101-4.

${ }^{4}$ Emery JL. Hilton DJ. The iron and copper concentrations of the liver in intrauterine life and in hacmolytic disease. Acta Paediatr Scand 1961;50:233-9.

10 Nakanuma Y, Karino T. Ohta G. Orcein positive granules in the hepatocytes in chronic intrahepatic cholestasis. Virchows Arch [Pathol Anat] 1979:382:21-30.

"Portes H. The particular half-cystine-rich copper protein of newborn liver. Relationship to metallothionein and subcellular localization in non-mitochondrial particles possibly 
representing heavy lysosomes. Biochem Biophys Res Commum 1974:56:661-8.

12 Gutteridge JM. Stocks J. Caeruloplasmin: physiological and pathological perspectives. CRC Crit Rev Clin Lab Sci 1981:14:257-329.

13 Hoogenradd TU. Van der Hamer CJA, Koevoet R, de Ruyter Kower EGWM. Oral zinc in Wilson's disease. Lancet 1978:ii: 1262 .

14 Abdulla M. Copper levels after oral zinc. Lancet 1979;i:616.

${ }^{15}$ Klevay LM. Hypercholesterolemia in rats produced by an increase in the ratio of zinc to copper ingested. Am J Clin Nutr 1973;26:1060-8.

${ }^{16}$ Fischer PW, Giroux A. Belonje B. Shah BG. The effect of dietary copper and zinc on cholesterol metabolism. Am J Clin Nutr 1980;33:1019-25.

17 Bogden JD. Thind IS, Lowriae B, Caterini H. Maternal and cord blood metal concentrations and low birth weight-a case control study. Am J Clin Nutr 1978:31:1181-7.

is Meadows JN, Ruse W, Smith MF, et al. Zinc and small babies. Lancet 1981;ii:1135-7.

19 Armstrong J. Dictary intakes of zinc, copper, calcium and iron in human pregnancy. Proc Nutr Soc 1982:41:147.

21 Tuttle S, Aggett PJ, Campbell D. MacGillivray I. Zinc and copper nutrition in human pregnancy: a longitudinal study in normal primigravidac and in primigravidae at risk of delivering a growth retarded baby. Am J Clin Nur 1985:41:1032-41.

21 Campbell-Brown M, Ward RJ, Haines AP, North WRS, Abraham R. McFadyen IR. Zinc and copper in Asian pregnancies-is there evidence for a nutritional deficiency? $\mathrm{Br} \mathrm{J}$ Obstet Gynaecol 1985;92:875-85.

22 Lyon TDB, Smith H, Smith LB. Zinc deficiency in the west of Scotland? A dietary intake study. J Nutr 1979;42:413-6.

23 Metcoff J. Costiloe JP. Gosby W. et al. Maternal nutrition and fetal outcome. Am J Clin Nutr 1981;34:708-21.

${ }^{24}$ Cherry FF, Bennett EA, Bazzano GS, et al. Plasma zinc in hypertension/toxemia and other reproductive variables in adolescent pregnancy. Am J Clin Nutr 1981:34:2367-75.

${ }^{25}$ Bloxam DL. Tan JCY. Parkinson CE. Non-protein bound zinc concentration in human plasma and amniotic fluid measured by ultra filtration. Clin Chim Acta 1984:144:81-93.

Correspondence to Professor F Cockburn. Royal Hospital for Sick Children, Yorkhill, Glasgow G3 8SJ, Scotland.

Received 20 June 1986 